\title{
VLIV AUTENTICITY NA PERCEPCI EXPONÁTU
}

\section{VIERA REZNÍCKKOVÁ}

https://doi.org/10.5817/MuB2019-2-5
Muzea bývají vnímána jako jakési chrámy autenticity, místa určená zejména pro uchovávání a vystavování autentických předmětů. Například Lucie Jagošová a Lenka Mrázová uvádí, že právě autentické sbírkové předměty jsou hlavní výhodou muzeí oproti ostatním edukačním institucím. ${ }^{1}$ Rovněž Julia Constanze Hampp konstatuje, že pravé, autentické předměty jsou považovány za hlavní atrakce muzeí. ${ }^{2}$ Ladislav Kesner zase poukazuje na to, že muzea bývají dokonce propagována jako místa, kde lze získat autentický prožitek. ${ }^{3}$ Muzea tedy údajně poskytují autenticitu na druhou - prostřednictvím autentických předmětů přináší autentický prožitek.

Ale je tomu skutečně tak? Jsou vystavované autentické předměty skutečně návštěvníky vnímány jako „lepší“ než repliky originálních předmětů nebo jiné substituty? Skutečně návštěvník muzea vnímá rozdíl mezi originálním, autentickým pazourkem a jeho replikou? Ano, již Jan Amos Komenský upřednostňoval objektové učení před náhražkami a prostým popisem ${ }^{4}$ a Jagošová a Mrázová jej

1 JAGOŠOVÁ, Lucie a Lenka MRÁZOVÁ. Objektové učení jako základ muzejní didaktiky. In Muzejní pedagogika dnes. Olomouc: Vydavatelství Univerzity Palackého, 2008, s. 225-236.

2 HAMPP, Julia Constanze. Die „Aura“ des Originals - Wahrheit oder Mythos? Wahrnehmung, Bewertung und Verarbeitung von authentischen Objekten in Ausstellungen von Wissenschafts- und Technikmuseen. Mnichov: Technische Universität München, TUM School of Education Lehrstuhl für Wissenschaftskommunikation, 2014. Dizertační práce.

3 KESNER, Ladislav. Marketing a management muzeí a památek. Praha: Grada, 2005, s. 116.

4 In BENEŠ, Josef. Kulturně výchovná činnost muzeí. 1. díl. Praha: Státní pedagogické nakladatelství, 1981, s. 52. vyzdvihují mezi ostatními pedagogickými aktivitami muzea, ${ }^{5}$ nicméně objektové učení počítá s tím, že daný předmět lze vidět ze všech stran, že se jej lze dotknout, což v muzeu téměř nikdy není možné. Je tedy autenticita sbírkového předmětu skutečně tak důležitá?

Předně je zapotřebí rozvést, co se autenticitou vlastně myslí. Silvie Rajčanová považuje autenticitu za hlavní podmínku toho, aby byl předmět posouzen jako originál. Přičemž ovšem současně rozlišuje dva druhy autenticity, a to autenticitu časoprostorovou a autenticitu personální. Časoprostorová autenticita odkazuje na původ díla, že vzniklo v určitém čase na určitém místě. Personální autenticitu vztahuje $\mathrm{k}$ autorovi daného díla, že jej bud' umělec sám vyrobil, nebo dohlížel či dal pokyny k jeho výrobě nebo autorizoval (signoval) výsledný produkt. Aby byl předmět považován za originál, musí být autentický v obou těchto rovinách. ${ }^{6}$ Obdobně Hampp ve své nejužší definici autentična označuje za autentický ten předmět, který je originální, byl ve fyzickém kontaktu s významnou historickou událostí, osobností či vývojem a vznikl v reálném světě za určitým účelem. Dále popisuje šest dimenzí autenticity - historie předmětu, jeho charizma (aura), vzácnost (ve smyslu

5 JAGOŠOVÁ, Lucie a Lenka MRÁZOVÁ. Objektové učení jako základ muzejní didaktiky. In Muzejní pedagogika dnes. Olomouc: Vydavatelství Univerzity Palackého, 2008, s. 225-236.

6 RAJČANOVÁ, Silvia. Originál a jeho aspekty vo vzt̉ahu k jeho náhradníkom. In Originál \& kópia v múzeu. Bratislava: Slovenská národná galéria, 2015, s. 12-15. rarity), prestiž, funkčnost a kompletnost předmětu. ${ }^{7}$

Z výše uvedených definic mi vyplývá, že aby návštěvník ocenil autenticitu předmětu, musí ji nejdřív rozpoznat, rozklíčovat. Pokud to nedokáže, je jedno, jestli se dívá na originál či kopii. K tomuto závěru de facto dospěl již Otto Schier v 19. století, který tvrdil, že je rozdíl mezi laickým návštěvníkem a návštěvníkem-odborníkem. Zatímco odborník vyžaduje autentické předměty, laik preferuje věci charakteristické, přehledně a úhledně uspořádané, tedy spokojí se i s imitacemi. ${ }^{8}$

Christina Goulding v rámci svého výzkumu situovaného do muzea Blists Hill Living Museum v Ironbridge, které je modelem vesnice 19. století a jejímž cílem je ukázat sociální a pracovní podmínky jejích obyvatel, zase rozdělila návštěvníky do tří skupin. ${ }^{9}$ První skupina, označená jako existencialisté, hledala v muzeu „staré dobré časy“, ovšem nejen v nostalgickém slova smyslu, ale i ve smyslu kontinuity, sepětí s minulostí. Autenticita předmětů pro ně nebyla důležitá. Zají-

7 HAMPP, Julia Constanze. Die „Aura“ des Originals - Wahrheit oder Mythos? Wahrnehmung, Bewertung und Verarbeitung von authentischen Objekten in Ausstellungen von Wissenschafts- und Technikmuseen. Mnichov: Technische Universität München, TUM School of Education Lehrstuhl für Wissenschaftskommunikation, 2014, s. 9, 26. Dizertační práce.

8 In JAGOŠOVÁ, Lucie, Otakar KIRSCH a kol. Muzejní profese a veřejnost 1: Nástin historie a současnosti vzájemných vztahů muzeí a jejich publika [online]. Brno: Masarykova univerzita, 2016, s. 15 [cit. 2019-04-29]. Dostupný z www: < https:// archeo-muzeo.phil.muni.cz/media/3056324/muzejni_profese_a_verejnost.pdf $>$.

9 GOULDING, Christina. Contemporary Museum Culture and Consumer Behavior. Journal of Marketing Management, 1999, roč. 15, č. 7, s. 647-671. 
mavostí je, že tato skupina nebyla složena pouze ze seniorů, pamětníků, ale i z mladých lidí. Druhá skupina, označená jako estéti, byla nejvíce kritická k přítomnosti, či spíše nepřítomnosti, autentických předmětů, a také nejbohatší a nejvzdělanější. Jejich návštěva rovněž spočívala ve vzpomínání na staré dobré časy, avšak toto vzpomínání bylo založeno na jejich zájmu o historii a umění, snaze pocítit ducha uplynulé doby a dojmu, že v současné době už se nedělají tak hezké a kvalitní věci. Zatímco první skupina v běžném životě zažívala pocity osamění a izolace, tedy ztrátu společenského kontaktu, druhá skupina trpěla ztrátou ideálů a smyslu života. Obě skupiny pak byly motivovány touto ztrátou $\mathrm{k}$ návštěvě muzea. Třetí skupina, označená jako společenská, byla motivována $\mathrm{k}$ návštěvě muzea svou referenční skupinou a návštěvu muzea vnímala jako společenskou událost. Autenticita předmětů pro ni byla zcela podružná. Každá skupina si pak v průběhu návštěvy muzea konstruovala svoji vlastní autentickou realitu (představu o minulosti), která ale nebyla založená na autentických předmětech, ale spíše na nostalgii a selektivním vnímání minulosti. Vzniklou konstrukci pak projektovala na exponáty v muzeu.

Lze přepokládat, že obdobné složení měli i návštěvníci repliky jeskyně v Lascaux. V „originální“ jeskyni byly objeveny malby z období paleolitu. Frekvence a intenzita turistických návštěv, vzhledem $\mathrm{k}$ množství pravděpodobně zejména laiků, však zapřričinily, že malby byly napadeny plísněmi a houbami a hrozilo jejich zničení. Proto byla jeskyně pro veřejnost uzavřena, ovšem s ohledem na její popularitu byla vyrobena její na milimetry přesná replika - Lascaux 2 . I tato se však těšila takovému zájmu, až došlo $\mathrm{k}$ jejímu poškození a musela být vyrobena další replika. ${ }^{10}$ Návštěvní-

10 MOREL-DLEDALLE, Myriame. The Copy as an Exhibit In Original, Copy, Fake, On the significance ci věděli, že se jedná o kopii, že neuvidí originální, autentické malby, přesto se přijeli na repliku podívat, i když dané malby si mohli prohlédnout i doma na internetu. Zjevně ani oni tedy nebyli motivováni $\mathrm{k}$ návštěvě autenticitou jeskyně.

\section{Naproti tomu Anne-Marie Hede} v průběhu svého výzkumu týkajícího se návštěvníků muzea význačné novozélandské spisovatelky Janet Frame zjistila, že návštěvníci zažívají silné pocity nelibosti, když zjistí, že v muzeu nejsou předměty patřící autorce, ale pouze předměty z období jejího života. ${ }^{11}$ Předměty tedy nebyly obdařeny personální autenticitou a i návštěvníci laici je pak vnímali jako neoriginály. Nicméně i přesto si dokázali vytvořit svoji autentickou realitu. Hede dokonce dospěla $\mathrm{k}$ závěru, že právě proto, že byli návštěvníci konfrontováni s neautentickými předměty, dokázali vnímat jejich časoprostorovou autenticitu a zejména jejich existenciální, celkovou autenticitu ve smyslu svědků konkrétní doby. Hede však zdůrazňuje, že k umožnění vnímání autenticity bylo nejprve zapotřebí odstranit pocity nelibosti, svým způsobem návštěvníky odblokovat, a to přiznáním a zdůvodněním umístění neautentických předmětů, nastavením scény (prostředí), $\mathrm{v}$ rámci které dochází ke styku s předměty, dále v umožnění volného a svobodného pohybu na této scéně $\mathrm{a} v$ aktivaci představivosti návštěvníka pomocí výše uvedených činitelů a návštěvníkova nitra, tj. jeho vzpomínkami, zkušenostmi atd. Tedy zde opět určitou roli hraje nostalgie.

Lze tedy shrnout, že pro návštěvníka není autenticita vystavených

\footnotetext{
of the object in History and Archaeology Museums [online]. ICOM, 2010, s. 124, 129 [cit. 2019-0429]. Dostupný z www: <http://network.icom. museum/fileadmin/user_upload/minisites/icmah/ publications/Actes-Shanghai-complet2.pdf $>$.

11 HEDE, Anna-Marie. A journey to the authentic: Museum visitors and their negotiation of the inauthentic. Journal of Marketing Management,
} 2010, roč. 26, č. 7-8, s. 686-705. předmětů podstatná, pakliže je srozuměn $s$ tím, že se nejedná o originály, a pakliže je mu ponechán dostatečný prostor, fyzický i mentální, pro rozvíjení vlastních vnitřních představ.

Hampp pak ve své dizertační práci doplňuje, že pakliže je vystavený objekt dobře popsán a srozumitelně zarámován do kontextu, návštěvník jej pozoruje stejně dlouho, at se jedná o originál či repliku. Rovněž zdůrazňuje, že pro návštěvníka je důležité vizuální a estetické zobrazení předmětu, nebot návštěvník lépe vnímá trojrozměrné, celé, funkční a hezké předměty, nikoli jeho autenticita. ${ }^{12}$ Tedy opět, pakliže jsou návštěvníkovi vytvořeny příznivé podmínky a prostor pro vlastní rozvoj, nezáleží mu na autenticitě exponátu.

Závěrem lze tedy říci, že pokud návštěvník nenavštíví muzeum se záměrem zhlédnout konkrétní originální předmět, ale je motivován jinými faktory, a pakliže k návštěvníkovi přistupujeme s respektem jako k myslící soběstačné bytosti a zajistíme mu př́ijemné, podnětné a rozvíjející prostředí, hraje autenticita vystavených předmětů pouze marginální roli.

\section{POUŽITÉ ZDROJE:}

BENEŠ, Josef. Kulturně výchovná činnost muzeí. 1. díl. Praha: Státní pedagogické nakladatelství, 1981.

GOULDING, Christina. Contemporary Museum Culture and Consumer Behavior. Journal of Marketing Management, 1999, roč. 15 , č. 7, s. 647-671.

ISSN 2333-6080.

HAMPP, Julia Constanze. Die „Aura“ des Originals - Wahrheit oder Mythos? Wahr-

12 HAMPP, Julia Constanze. Die „Aura“ des Originals - Wahrheit oder Mythos? Wahrnehmung, Bewertung und Verarbeitung von authentischen Objekten in Ausstellungen von Wissenschafts- und Technikmuseen. Mnichov: Technische Universität München, TUM School of Education Lehrstuhl für Wissenschaftskommunikation, 2014, s. 22-23. Dizertační práce. 
nehmung, Bewertung und Verarbeitung von authentischen Objekten in Ausstellungen von Wissenschafts- und Technikmuseen. Mnichov: Technische Universität München, TUM School of Education Lehrstuhl für Wissenschaftskommunikation, 2014. 132 s. Dizertační práce.

HEDE, Anna-Marie. A journey to the authentic: Museum visitors and their negotiation of the inauthentic. Journal of Marketing Management, 2010, roč. 26, č. 7-8, s. 686-705. ISSN 2333-6080.

JAGOŠOVÁ, Lucie, Otakar KIRSCH a kol. Muzejní profese a veřejnost 1: Nástin historie a současnosti vzájemných vztahů muzeí a jejich publika [online]. Brno: Masarykova univerzita, 2016. 111 s. [cit. 2019-0429]. Dostupný z www: <https://archeo- muzeo.phil.muni.cz/media/3056324/ muzejni_profese_a_verejnost.pdf $>$. ISBN 978-80-210-8432-2. https://doi. org/10.5817/CZ.MUNI.M210-8432-2016 JAGOŠOVÁ, Lucie a Lenka MRÁZOVÁ. Objektové učení jako základ muzejní didaktiky. In Muzejní pedagogika dnes. Olomouc: Vydavatelství Univerzity Palackého, 2008, s. 225-236. ISBN 978-80-244-1993-0.

KESNER, Ladislav. Marketing a management muzeí a památek. Praha: Grada, 2005. 304 s. ISBN 978-80-247-6364-4.

MOREL-DLEDALLE, Myriame. The Copy as an Exhibit. In Original, Copy, Fake, On the significance of the object in History and Archaeology Museums [online] ICOM, 2010, s. 124, 129 [cit. 2019-04-
29]. Dostupný z www: < http://network. icom.museum/fileadmin/user_upload/ minisites/icmah/publications/ActesShanghai-complet2.pdf $>$.

RAJČANOVÁ, Silvia. Originál a jeho aspekty vo vztahu $\mathrm{k}$ jeho náhradníkom. In Originál \& kópia v múzeu. Bratislava: Slovenská národná galéria, 2015, s. 12-15.

\section{VIERA ŘEZNíČKOVÁ}

studentka muzeologie, Ústav archeologie a muzeologie, Filozofická fakulta, Masarykova univerzita, Brno, Česká republika 